\title{
Growth Hormone Secretion in Subjects with Ovarian Dysgenesis and Turner's Syndrome
}

\author{
S. R. MEADOW,^ B. J. BOUCHER, K. MASHITER, M. N. R. KING, \\ and L. STIMMLER \\ From the Departments of Paediatrics and Medicine, and the Paediatric Research Unit, Guy's Hospital, London S.E.1
}

Short stature is one of the major disabilities for people with ovarian dysgenesis and Turner's syndrome. There have been contradictory reports of the plasma growth hormone level in children with these conditions in whom this estimation has been made (Fraccaro, Gemzell, and Lindsten, 1960; M. Davidson, 1967, personal communication). Therefore, in the present studies growth hormone secretion has been assessed in 15 such patients following stimulation by insulin-induced hypoglycaemia.

\section{Material and Methods}

The patients were aged from $5 \frac{1}{2}-17$ years. Their height was well below the 3 rd centile. Two-thirds had webbing of the neck as well as short stature (Turner's syndrome in the female). The remainder of the patients did not have webbing of the neck but were of short stature (ovarian dysgenesis; for nomenclature see Polani (1961)).

Previous chromosomal analysis had shown them to have 45 chromosomes with an XO sex chromosome complement. Mosaicism was excluded as far as this was feasible by counting and analysing a large number of cells of blood lymphocytes and skin fibroblast cultures (Miss R. Angell).

Blood specimens were obtained after intravenous infusion of insulin, $0.1 \mathrm{unit} / \mathrm{kg}$. Blood glucose was estimated by the automated ferricyanide method (Whichelow et al., 1967) and the growth hormone by a modified radio immunoassay method (Hartog et al., 1964).

Six of the patients, all over the age of 15 years, had cyclical oestradiol and norethisterone therapy which was stopped 10 days before the test.

\section{Results}

Of the 15 patients, 14 showed a rise of plasma growth hormone levels during the test (Table). Hypoglycaemia was most marked within the first 30 minutes after insulin injection, but maximal

Received March 19, 1968.

* Requests for reprints should be sent to S.R.M. at Dept. of Paediatrics, Guy's Hospital, London S.E.1. growth hormone levels usually occurred later in the test. Case 6 was inadvertently not given insulin; however, despite the absence of hypoglycaemia blood levels of growth hormone increased during the test, while Case 13 had persistent low growth hormone levels despite a marked hypoglycaemic response to insulin.

\section{Discussion}

The rises in blood growth hormone levels found in this study (see Fig.) are comparable to those reported in a series of children of short stature without hypopituitarism (Stimmler and Brown, 1967).

They found that an increase of growth hormone to $10 \mathrm{ng} . / \mathrm{ml}$. in response to insulin was adequate to exclude hypopituitarism. Occasionally children who are not thought to be hypopituitary fail to reach this level of secretion despite provocation, and Case 13 may be in this category. The results in

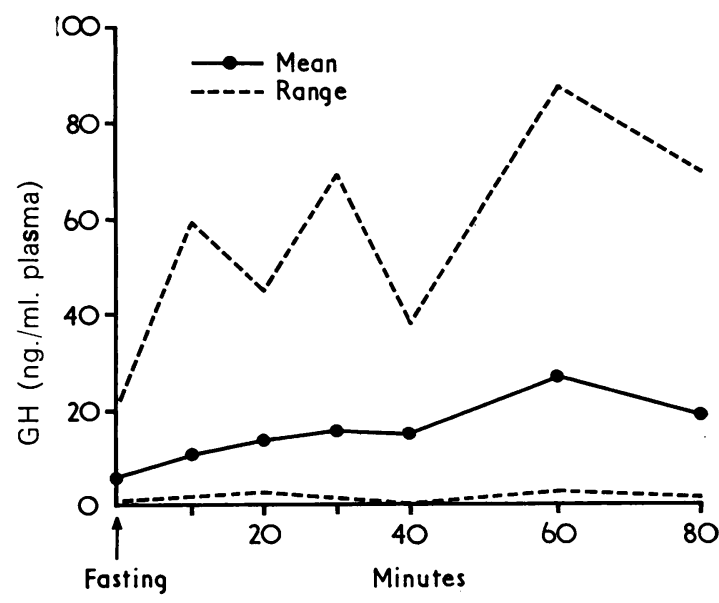

FIG.-Mean and range of plasma growth hormone response in the insulin test in 15 patients with ovarian dysgenesis and Turner's syndrome. 
TABLE

Plasma Growth Hormone (GH) (ng./ml.) and Blood Glucose (mg./100 ml.) Levels after Insulin, in 15 Children with Ovarian Dysgenesis and Turner's Syndrome

\begin{tabular}{|c|c|c|c|c|c|c|c|c|c|}
\hline Case No. & Age (yr.) & & Fasting & 10 & 20 & 30 & 40 & 60 & $80 \mathrm{~min}$ \\
\hline 1 & $10 \frac{1}{2}$ & GH & 3 & 60 & 25 & 8 & 38 & - & 3 \\
\hline & & Glucose & 79 & 57 & 34 & - & 57 & 一 & 73 \\
\hline \multirow[t]{2}{*}{2} & 10 & GH & 3 & 6 & 15 & 17 & 10 & 13 & 17 \\
\hline & & Glucose & 62 & 36 & 18 & 16 & 39 & 39 & 47 \\
\hline \multirow[t]{2}{*}{3} & $7 \frac{1}{2}$ & $\mathrm{GH}$ & 15 & 15 & 10 & 13 & 25 & 75 & - \\
\hline & & Glucose & 76 & 50 & 33 & 56 & 66 & 64 & - \\
\hline \multirow[t]{2}{*}{4} & $5 \frac{1}{2}$ & GH & 12 & 8 & 9 & - & 23 & 8 & 14 \\
\hline & & Glucose & 65 & 32 & 29 & 41 & 42 & 45 & 52 \\
\hline \multirow[t]{2}{*}{5} & 8 & GH & 10 & 15 & 18 & 10 & 13 & 8 & - \\
\hline & & Glucose & 71 & 54 & 23 & 29 & 36 & - & - \\
\hline \multirow[t]{2}{*}{6} & 10 & $\mathrm{GH}$ & 21 & - & 39 & 11 & 13 & - & 7 \\
\hline & & Glucose & 78 & - & 83 & 79 & 74 & - & 82 \\
\hline \multirow[t]{2}{*}{7} & $16_{2}^{\frac{1}{2}}$ & GH & 7 & 6 & 10 & 12 & 35 & 88 & 11 \\
\hline & & Glucose & 73 & 50 & 20 & 26 & 42 & 51 & 64 \\
\hline \multirow[t]{2}{*}{8} & 14 & GH & 1 & 6 & 6 & 4 & 10 & 3 & 2 \\
\hline & & Glucose & 68 & 67 & 60 & 56 & 55 & 54 & $5 \overline{5}$ \\
\hline \multirow[t]{2}{*}{9} & $13 \frac{1}{2}$ & $\mathrm{GH}$ & 6 & 5 & 4 & 6 & 5 & 13 & 11 \\
\hline & & Glucose & 65 & 59 & 36 & 31 & 42 & 63 & 89 \\
\hline \multirow[t]{2}{*}{10} & 16 & GH & 1 & 2 & 11 & - & 19 & - & 25 \\
\hline & & Glucose & - & - & - & - & - & - & - \\
\hline \multirow[t]{2}{*}{11} & 17 & GH & 4 & 3 & 7 & - & 6 & 15 & 7 \\
\hline & & Glucose & 80 & 55 & 30 & - & 50 & 63 & 77 \\
\hline \multirow[t]{2}{*}{12} & 16 & $\mathrm{GH}$ & 3 & 3 & 8 & 17 & 0 & 22 & 70 \\
\hline & & Glucose & 70 & 52 & 23 & 32 & 40 & 50 & 80 \\
\hline \multirow[t]{2}{*}{13} & 17 & $\mathrm{GH}$ & 4 & 5 & 3 & 2 & 1 & 6 & 5 \\
\hline & & Glucose & 64 & 46 & 20 & 16 & 34 & 50 & 54 \\
\hline \multirow[t]{2}{*}{14} & $14 \frac{1}{2}$ & $\mathrm{GH}$ & 1 & 6 & 3 & 6 & 2 & 8 & 11 \\
\hline & & Glucose & 63 & 39 & 25 & 13 & 10 & 25 & 35 \\
\hline \multirow[t]{2}{*}{15} & 17 & GH & 8 & 9 & 45 & $>70$ & - & $>70$ & $>70$ \\
\hline & & Glucose & 81 & 52 & 38 & 37 & - & 71 & 71 \\
\hline
\end{tabular}

Cases $10-15$ which had cyclical hormone therapy did not differ from the others.

XO subjects with dysgenetic ovaries do not grow normally even though they have normal growth hormone levels. They may lack a factor needed for growth other than growth hormone; alternatively their growth hormone may be different or there may be a lack of tissue response to normal growth hormone. This last hypothesis was supported by the finding of high fasting growth hormone levels in 8 dwarfed adults with Turner's syndrome by Lindsten et al. (1967), but our data do not confirm that finding. The results of administering growth hormone to a few children with 'Turner's syndrome' have been reported. Both Forbes et al. (1960) and Escamilla et al. (1960) reported nitrogen retention after growth hormone was administered, though it was less than occurred in hypopituitary patients similarly treated. The increase in linear growth reported by Forbes et al. (1960) after growth hormone was also less than would be expected in hypopituitary children.

\section{Summary}

Growth hormone secretion was estimated in 15
XO subjects with ovarian dysgenesis and Turner's syndrome in response to insulin-induced hypoglycaemia. The increases in plasma growth hormone level were comparable to those that have previously been described in small but otherwise normal children.

We are greateful to Professor P. E. Polani for his help and for permission to study the patients who had been referred to him. We thank also Miss B. J. Alexander for her invaluable assistance, Miss R. Angell who carried out the chromosome studies, and Miss Ruth Elias who estimated the blood glucose levels.

\section{REFERENCES}

Escamilla, R. F., Hutchings, J. J., Deamer, W. C., and Li, C. H (1960). Clinical experiences with human growth hormone(LI) in pituitary infantilism and gonadal dysgenesis. Acta endocr. (Kbh.), Suppl. 51, 253.

Forbes, A. P., Jacobsen, J. G., Caroll, E. L., and Pechet, M. M. (1960). The nature of the growth arrest in gonadal dysgenesis : response to human growth hormone. ibid., Suppl. 51, 251.

Fraccaro, M., Gemzell, C. A., and Lindsten, J. (1960). Plasma level of growth hormone and chromosome complement in four patients with gonadal dysgenesis (Turner's syndrome). ibid., 34, 496. 
Hartog, M., Gaafar, M. A., Meisser, B., and Fraser, R. (1964). Immunoassay of serum growth hormone in acromegalic patients. Brit.med. F., 2, 1229.

Lindsten, J., Cerasi, E., Luft, R., and Hultquist, G. (1967). The occurrence of abnormal insulin and growth hormone (HGH) responses to sustained hyperglycaemia in a disease with sex chromosome aberrations (Turner's syndrome). Acta endocr. $(K b h), 56,107$.

Polani, P. E. (1961). Turner's syndrome and allied conditions. Brit. med. Bull., 17, 200.

Stimmler, L., and Brown, G. A. (1967). Growth hormone secretion provoked by insulin-induced hypoglycaemia in children of short stature. Arch. Dis. Childh., 42, 232.

Whichelow, M. J., Wigglesworth, A., Cox, B. D., Butterfield, W. J. H., and Abrams, M. E. (1967). Critical analysis of blood sugar measurements in diabetes detection and diagnosis. Diabetes, 16, 219. 